\title{
Isolation and Characterization of Mutants Resistant against Chlorate of Bacillus licheniformis
}

\author{
By J. A. SCHULP AND A. H. STOUTHAMER \\ Biologisch Laboratorium der Vrije Universiteit de Boelelaan I087, \\ Amsterdam-Buitenveldert, The Netherlands
}

(Received 2I March I972)

\begin{abstract}
SUMMAR Y
From Bacillus licheniformis S244, $45 \mathrm{chl}$ deletion mutants have been isolated which belong to six groups. In four groups the identity of the auxotrophic markers deleted has been established: his-2, ura-I, $\arg -3$ and trp-I. Furthermore, a leu and a glu marker were found in the two other groups of deletion mutants. From $B$. licheniformis SI026, derived from strain ATCC 9945A, 36 single site mutants were obtained and classified into eight groups, $\operatorname{chl} A$ to $H$, by transformation and phage SPI5-mediated transduction. The glu deletion comprises the mutations chl $A$ and $B$. In total, $\mathrm{r}_{3} \mathrm{chl}$ mutations have been found and there may be up to $13 \mathrm{chl}$ genes. Of the single-site $\mathrm{chl}$ mutations, only $\mathrm{chl} E$ is linked with a known reference marker, $u r a$-I. All $\mathrm{chl}$ mutants are unable to form nitrate reductase under conditions of oxygen shortage. This nitrate reductase is mainly associated with the cytoplasmic membrane. Most mutations have pleiotropic effects: (i) retarded growth under anaerobic conditions; (ii) an increased sensitivity to penicillin and related antibiotics; (iii) completely altered membrane protein patterns on acrylamide-SDS gels.

In the wild-types, II membrane protein bands are observed. There are only small, quantitative differences between membrane protein patterns of cells cultivated aerobically or anaerobically. Membrane protein patterns of the $c h l$ mutants are most different from those of the wild-types after anaerobic cultivation. Differences include appearance of a new protein band, disappearances, decreases, doublings and often large increases of other protein bands. Aerobically, the mutants have membrane protein patterns less different from those of the wild-types. Differences include appearance of a new protein band, decrease and disappearance of protein bands. An explanation for all these changes may be a wholesale disorganization of protoplasmic membrane biosynthesis.
\end{abstract}

\section{INTRODUCTION}

Many bacteria are able to use nitrate instead of oxygen as a terminal electron acceptor under anaerobic conditions. In this process nitrate is reduced to nitrite by the enzyme nitrate reductase. Nitrate reductase also reduces chlorate, and the product chlorite is toxic. Consequently, nitrate reductaseless mutants can be obtained by plating bacteria on chloratecontaining media and incubating anaerobically (Piéchaud et al. 1967; Stouthamer, 1967).

In Enterobacteriaceae both deletion and single-site chlorate resistant $(c h l)$ mutants have been obtained by this method. In Escherichia coli, five chl loci have been mapped by deletion and linkage mapping methods (Puig \& Azoulay, 1967; Adhya, Cleary \& Campbell, 1968; Venables \& Guest, 1968; Guest, 1969; Puig, Azoulay, Gendre \& Richard, I969; McGregor \& Schnaitman, I97I). In Salmonella typhimurium seven chl loci have been mapped by deletion and linkage mapping (Stouthamer, 1969; Sanderson, 1970; Stouthamer 
\& Bettenhaussen, 1970) and in Klebsiella aerogenes three chl loci have been mapped by deletion analysis alone (Stouthamer \& Pietersma, I970).

Chlorate-resistant mutants show different pleiotropic effects depending upon the bacterial species concerned. In Escherichia coli chl mutants, in addition to the formation of nitrate reductase, the formation of formic hydrogenase is affected (Guest, 1969; Ruiz-Herrera, Showe \& de Moss, I969). In Proteus and Salmonella effects are found on the formation of reductase for thiosulphate, tetrathionate and chlorate (Piéchaud et al. 1967; de Groot \& Stouthamer, 1969; Stouthamer, 1969). All these enzymes are membrane bound. The pleiotropic effect is explained by the hypothesis that some structural component of the membrane-bound multi-enzyme complex has been lost or altered, so that not only nitrate reductase but also other enzymes cannot be complexed into the membrane in an active form. In $E$. coli chl mutants alterations in the membrane protein composition have been observed (Schnaitman, I969; Onodera, Rolfe \& Bernstein, 1970; McGregor \& Schnaitman, I97I).

For the study of chlorate-resistant mutants of a Gram-positive organism we have chosen Bacillus licheniformis because it is a denitrifying species; much of the regulation of nitrate reductase formation is known (Schulp \& Stouthamer, 1970), and it is accessible to genetic analysis by transformation (Gwinn \& Thorne, 1964) and transduction (Taylor \& Thorne, I963).

In the present paper the isolation and genetic classification of $\mathrm{chl}$ single site and deletion mutants will be described. Some of these mutations have been mapped. An analysis of the membrane protein composition of the mutants will be presented, together with some additional characterization of the mutants.

\section{METHODS}

Bacterial strains. The parent strains and relevant markers are listed in Table I. Except s244, all strains were derived from ATCC 9945A. Strains were maintained on slopes of Oxoid Brain Heart Infusion agar (BHI) and stored at $4{ }^{\circ} \mathrm{C}$. They were transferred to fresh agar slopes every 3 weeks; asporogenous strains every 4 days. BHI agar for thymine auxotrophs was fortified with $10 \mu \mathrm{g} / \mathrm{ml}$ thymine. The map positions of the reference markers have been determined by Tyeryar, Lawton \& McQuillan (I968), Rogolsky (I970) and McCuen \& Thorne (197I).

Media. NBY, NBYG, $\mathrm{NBYGNO}_{3}$ and $\mathrm{NBYNO}_{3}$ have been described previously (Schulp \& Stouthamer, I970). If solid media were required $2 \%$ Oxoid agar no. I was added; for semisolid media $0.5 \%$ agar was used. NBYGChl was prepared by addition of $6.25 \mathrm{~g} / \mathrm{l}$ of $\mathrm{KClO}_{3}$ to NBYG. The minimal medium was that of Thorne \& Stull (I966), without sodium glutamate. Growth requirements for auxotrophs were added according to Thorne \& Stull (1966). Minimal plates for thy auxotrophs contained $100 \mu \mathrm{g} / \mathrm{ml}$ thymine; for glutamic acid auxotrophs sodium glutamate $200 \mu \mathrm{g} / \mathrm{ml}$ was used. For scoring spo colonies the minimal medium was fortified with two $\mathrm{IO}^{-5} \mathrm{M}-\mathrm{MnSO}_{4}$ (Rogolsky, I970). TM and BLSG media for transformation were prepared according to Thorne \& Stull (1966). PA medium for transduction was prepared according to Thorne (1962). Later a modified medium PA was used (Taylor \& Goldberg, I97I). PA medium containing $0 . \mathrm{I} \%(\mathrm{w} / \mathrm{v})$ glucose was used to grow chl mutants.

Cultural conditions. All solid media were incubated at $37^{\circ} \mathrm{C}$. NBYGChl plates were incubated anaerobically under nitrogen and the anaerobic jar was flushed three times with nitrogen. To score nitrate utilization on $\mathrm{NBYNO}_{3}$ plates, the plates were incubated under nitrogen containing less than ro p.p.m. oxygen; the jar was flushed seven times with this 
Table I. Parent strains and strains with reference markers of Bacillus licheniformis

\begin{tabular}{|c|c|c|c|}
\hline Strain no. & Markers & $\begin{array}{c}\text { Original } \\
\text { designation }\end{array}$ & Origin \\
\hline S244 & - & 430 & J. Woldendorp, Wageningen \\
\hline S292 & - & ATCC 9945 A & C. B. Thorne, Fort Detrick \\
\hline $\mathrm{SIO26}$ & str pep-I & FDOI & J. D. Sherratt, Edinburgh \\
\hline SI I 68 & $u r a-1$ & FDO8 & \\
\hline SI I 69 & pep-I pur-1 leu-2 his-2 & FDI9 & \\
\hline SI 170 & pep-I met-4 & M3R-I & \\
\hline SI 17 I & pep-I lys-8 & $M 2 R-1$ & M. Rogolsky, Utah \\
\hline SI I 77 & spo $L R 26$ & LR 26 & \\
\hline SI 179 & spo LR 9 & LR9 & \\
\hline $\sin 328$ & pep-I & & $\operatorname{si177} \stackrel{t d}{\rightarrow} \operatorname{si1} 171$ \\
\hline si329 & pep-I leu-2 his-2 & & sII $77 \rightarrow$ SII 69 \\
\hline S1333 & pep-1 arg-3 & MI8R-I & \\
\hline SI 1337 & pep-I str-I thi-I & MR-I & \\
\hline SI 338 & pep-I pur-I & MI7R-I & M. Rogolsky, Utah \\
\hline SI 339 & pep-I trp-I & FDO9 & \\
\hline S I 340 & pep-I $g l y-3$ & $\mathrm{M} 28$ & \\
\hline SI 393 & pep-I ile & & From si 328 by NG treatment \\
\hline SI 397 & pep-I thy & & $\begin{array}{l}\text { As above, followed by aminopterin } \\
\text { enrichment }\end{array}$ \\
\hline SI 404 & pep-7 ade-2 & & C. B. Thorne, Amherst, Massachusetts \\
\hline
\end{tabular}

Abbreviations used: ura, uracil; pur, purine; leu, leucine; his, histidine; met, methionine; lys, lysine; arg, arginine; thi, thiamine; trp, tryptophan; gly, glycine; ile, isoleucine; thy, thymine; ade, adenine requirement; pep, inability to form glutamyl polypeptide; spo, inability to sporulate; str, resistance to streptomycin; $\stackrel{\text { td }}{\rightarrow}$, obtained by SP 15 -mediated transduction.

gas. A mixture of I $\mathrm{g}$ kieselguhr, O.I g pyrogallol and $\mathrm{O}_{\mathrm{I}} \mathrm{g} \mathrm{NaHCO}_{3}$ wrapped in paper were present in the jar to remove the last traces of oxygen.

Batch cultures were grown at $37^{\circ} \mathrm{C}$ in a New Brunswick Micro Ferm Laboratory fermentor in a 51 jar containing 21 of medium with vigorous aeration (Io 1 air $/ \mathrm{min}$, agitation $650 \mathrm{rev} . / \mathrm{min})$ or weak aeration $(2 \mathrm{lair} / \mathrm{min}$, agitation $200 \mathrm{rev} . / \mathrm{min})$ or anaerobically (nitrogen, agitation $100 \mathrm{rev} . / \mathrm{min}$ ). The medium in the jar was inoculated with $3 \times 100 \mathrm{ml}$ of culture in NBY, shaken overnight at $250 \mathrm{rev} . / \mathrm{min}$ at $37^{\circ} \mathrm{C}$ in a $500 \mathrm{ml}$ bottle. The medium was maintained at $\mathrm{pH}_{7}$ by a New Brunswick Automatic $\mathrm{pH}$ Controller using $0.5 \mathrm{~N}-\mathrm{NaOH}$. Bacterial density was measured by extinction at $660 \mathrm{~nm}(E 660)$ in a Unicam SP 600 spectrophotometer.

Isolation of auxotrophic mutants. Auxotrophic mutants were isolated from si 328 by an $N$-methyl- $N$-nitroso- $N$-guanidine (NG) treatment (Rogolsky, I969). Thymine auxotrophs were isolated after aminopterin enrichment following NG mutagenesis (de Haan, Stouthamer, Felix \& Mol, 1963).

Propagation and assay of phage SPI5. Phage SPI5 was propagated on Bacillus subtilis W23 str by an overlay technique similar to that described by McCuen \& Thorne (197I) Sufficient moisture was maintained by packaging the Petri dishes in a polythene bag with a piece of dripping wet cotton-wool. In this way, phage titres of 2.5 to $5 \times 10^{9}$ p.f.u. $/ \mathrm{ml}$ were obtained. Phage was assayed in a similar manner.

Transduction procedure. Donor lysate preparation and transduction procedure were those of Rogolsky (1970). A $3 \mathrm{ml}$ sample of phage lysate and $3 \mathrm{ml}$ of acceptor cells were used, concentrated and spread on to minimal medium plates supplemented where necessary with nutritional requirements, or on to $\mathrm{NBYNO}_{3}$ plates. This yielded 50 to 500 colonies/ plate. Modified PA medium (Taylor \& Goldberg, 1971) gave better results. 
Testing recombinants for chl markers. In most crosses chl was the unselected marker. Recombinants were tested for chlorate resistance by streaking on to NBYGChl plates and incubating anaerobically. Chlorate-resistant recombinants showed dense and 'closed' growth like the $c h l$ donor strains; chlorate-sensitive recombinants like the chlorate-sensitive acceptor strains produced only a few colonies.

Nitrate and nitrite reduction. Nitrate and nitrite reduction were tested qualitatively by inoculating $5 \mathrm{ml}$ of $\mathrm{NBYGNO}_{3}$ or NBYG containing $0.0 \mathrm{I} \% \mathrm{NaNO}_{2}$. After overnight or 2 day incubation at $37^{\circ} \mathrm{C}$, presence of nitrite was checked with Boehringer-Mannheim nitrite test strips.

Testing for antibiotic sensitivities. Bacteria were grown in NBY overnight on the shaker at $37^{\circ} \mathrm{C}$ and $250 \mathrm{rev} . / \mathrm{min} ; \mathrm{O} \cdot \mathrm{I} \mathrm{ml}$ was spread on to Oxoid BHI agar plates and sensitivity discs were placed on the plates. The diameter of inhibition zones was measured after incubation at $37^{\circ} \mathrm{C}$ overnight. The discs used were: chloramphenicol, $10 \mu \mathrm{g}$; methicillin, Io $\mu \mathrm{g}$; colistin, $50 \mu \mathrm{g}$; fusidic acid, Io $\mu \mathrm{g}$; kanamycin, $5 \mu \mathrm{g}$; neomycin, $10 \mu \mathrm{g}$; novobiocin, $5 \mu \mathrm{g}$; cloxacillin, $5 \mu \mathrm{g}$; ampicillin, 5 and $25 \mu \mathrm{g}$; gentamycin, $10 \mu \mathrm{g}$; cephaloridin, $25 \mu \mathrm{g}$; colistin methane sulphonate, $200 \mu \mathrm{g}$; sulphafurazole, $500 \mu \mathrm{g}$; carbenicillin, $100 \mu \mathrm{g}$; sulfamethoxazole trimethoprim, $25 \mu \mathrm{g}$; tetracycline, $50 \mu \mathrm{g}$.

Isolation of DNA. DNA was isolated according to Gwinn \& Thorne (1964). No recrystallization in saline citrate was performed. The final concentration of the DNA solution obtained was $70 \mu \mathrm{g} / \mathrm{ml}$.

Transformation procedure. The transformation method was that of D. J. Sherratt (personal communication). Recipient cells were shaken overnight at $37^{\circ} \mathrm{C}$ in BLSG medium and then diluted 20 -fold with TM medium. To $0.9 \mathrm{ml}$ of this cell suspension $0 . \mathrm{I} \mathrm{ml}$ of suitably diluted DNA was added and the mixture shaken for $2 \mathrm{~h}$, then $9 \mathrm{ml}$ TM without glucose was added and the suspension centrifuged at $3000 \mathrm{rev} . / \mathrm{min}$. The cells were then washed twice with Io $\mathrm{ml}$ of TM without glucose resuspended in $0.5 \mathrm{ml} \mathrm{TM}$ without glucose and $0.2 \mathrm{ml}$ of the suspension was spread on to $\mathrm{NBYNO}_{3}$ plates which were incubated anaerobically. TM without glucose for washing and resuspending prevented glucose supported anaerobic growth on $\mathrm{NBYNO}_{3}$ plates.

Isolation of peripheral membranes and mesosomes. Bacteria were cultivated in batch cultures to an $E 660$ of I 0 or until the beginning of the stationary phase if that occurred earlier. They were harvested by centrifugation at $10000 \mathrm{~g}$, at $2{ }^{\circ} \mathrm{C}$ for $15 \mathrm{~min}$. Peripheral membranes and mesosomes were isolated according to Reaveley \& Rogers (1969). Both peripheral membranes and mesosomes from I 1 of culture were resuspended in $4 \mathrm{ml}$ of I $\mathrm{M}-\mathrm{NaCl}+0.02 \mathrm{M}^{-\mathrm{MgSO}_{4}}$ and used for enzyme assays.

Preparation of samples for polycrylamide gel electrophoresis. The membrane pellet from I 1 of culture was homogenized in $4 \mathrm{ml}$ of $0.0 \mathrm{I}$ M-sodium phosphate buffer, $\mathrm{pH} 7^{\circ} \mathrm{O}$, with $\mathrm{I} \%$ sodium dodecyl sulphate (SDS) and I \% mercaptoethanol, incubated at $37^{\circ} \mathrm{C}$ for $2 \mathrm{~h}$ and centrifuged at $24{ }^{\circ} \mathrm{C}$ at $\mathrm{I} 8000 \mathrm{rev} . / \mathrm{min}$. The supernatant was dialysed overnight against I 1 of $0.0 \mathrm{I}$ M-sodium phosphate buffer with $0.1 \%$ SDS and $0.1 \%$ mercaptoethanol.

Polyacrylamide gel electrophoresis. Gel electrophoresis was performed according to Weber \& Osborn (1969) on $7 \mathrm{~cm}$ gels with $7 \mathrm{~mA} /$ gel for $5 \mathrm{~h}$. By that time the bromphenol blue front had migrated $65 \mathrm{~mm}$. The amount of protein applied varied from 50 to $200 \mu \mathrm{g} /$ gel. Gels were stained in a $\mathrm{I} \%$ amido black IoB solution in $7 \%$ acetic acid; surplus of stain was removed by rinsing 24 to $48 \mathrm{~h}$ in a gently stirred $7 \%$ acetic acid solution. Gels were stored in $7 \%$ acetic acid and scanned on a Kipp densitometer.

Molecular weights were calculated from the $R_{m}$ values according to Weber \& Osborn 
(I969). A standard curve, made with seven proteins (pyruvate kinase, glutamate dehydrogenase, aldolase, alcohol dehydrogenase and trypsin) was in good agreement with that of Weber \& Osborn (1969).

Electron microscopy. Membrane pellets were fixed according to Ryter \& Kellenberger (1958 $a$ ), dehydrated in graded solutions of acetone and embedded in Vestopal-A (Ryter \& Kellenberger, $1958 b$ ). Thin sections were cut on an LKB Ultratome with glass knives, placed on formvar and carbon copper grids and stained with uranyl acetate (Stempak \& Ward, 1964). Negatively stained specimens were prepared by the method of Parson (1963)

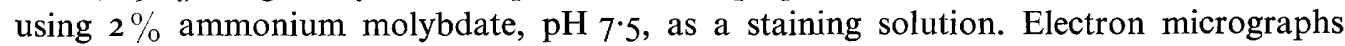
were taken with a Philips EM 300 electron microscope operated at $80 \mathrm{kV}$ using a $50 \mu \mathrm{m}$ objective aperture.

Ribosomal proteins. Purified ribosomes were a gift of Mr Joh. Brouwer, Biochemisch Laboratorium der Vrije Universiteit. They had been prepared according to van DijkSalkinoja, Stoof \& Planta (1970). The pellet was dissolved in phosphate-SDS-mercaptoethanol buffer and treated as the membrane preparations.

Other techniques. Preparation of sonic extracts and measurement of acid formation have been described previously (Schulp \& Stouthamer, 1970).

Oxygen uptake was measured by standard Warburg techniques. Cytochrome spectra were recorded as difference spectra between oxygen oxidized and dithionite reduced cell suspensions on an Aminco Chance Double Beam Spectrophotometer.

Nitrate reductase activity was measured according to Lowe \& Evans (I964); the assay mixtures were incubated for $15 \mathrm{~min}$ at $37^{\circ} \mathrm{C}$. Protein was estimated according to Lowry, Rosebrough, Farr \& Randall (I95I).

\section{RESULTS}

Isolation of chlorate-resistant mutants. Bacillus licheniformis $\mathbf{S} 244$ was shaken overnight at $37^{\circ} \mathrm{C}$ in NBY, diluted $\mathrm{I}: \mathrm{ro}$, shaken for a further $4 \mathrm{~h}$ and diluted 50- and roo-fold. Samples of each dilution (O. I ml) were plated on to $40 \mathrm{NBYGChl}$ plates and incubated anaerobically at $37^{\circ} \mathrm{C}$ for 2 days. For selection of $c h l$ deletion mutants plates were replicated on to minimal medium and NBY. After incubation at $37^{\circ} \mathrm{C}$ potential auxotrophs were isolated, their deficiencies were identified and they were characterized more closely (see Table 2).

In 15 experiments the percentage of deletion mutants among the chlorate-resistant mutants was $0.15 \%$. Deletion mutants never reverted to chlorate sensitivity or prototrophy. It was impossible to transduce these mutants either to prototrophy or chlorate sensitivity although they could act as donors in SPI 5-mediated transduction crosses.

No deletion mutants were obtained in this way from the transformable strain sio26 but 36 single-site chlorate-resistant mutants were obtained which had a low rate of reversion.

Genetic classification of the single-site mutants. Twenty of the $36 \mathrm{chl}$ mutants were readily transformable. They have been classified by reciprocal transformation crosses into six groups designated $c h l A$ to $F$ (Table 3 ). The remaining I 6 mutants were used as donors in transformation crosses with representatives of groups $c h l A$ to $F$ as receptors. Thirteen of the I 6 mutants were classified into groups $\operatorname{chl} A, D$ and $E$. The three remaining strains which did not belong to one of the previous groups have been classified into two different groups $c h l G$ and $H$ by reciprocal SPI 5-mediated transduction.

Relationship between single-site and deletion mutations. To study whether the deletions overlapped the single-site mutations, donor DNA and SPI 5 donor lysates were prepared from all the deletion mutants. Representatives of the groups $c h l A$ to $H$ were used as 
Table 2. Chlorate resistant deletion mutants of Bacillus licheniformis $\mathrm{S} 244$

Experimental details are given in Results (Isolation of chlorate-resistant mutants).

\begin{tabular}{|c|c|c|}
\hline Type & $\begin{array}{c}\text { No. of } \\
\text { experiments }\end{array}$ & $\begin{array}{c}\text { No. of } \\
\text { mutants obtained }\end{array}$ \\
\hline $\operatorname{del}(u r a \operatorname{chl} l)$ & 6 & 20 \\
\hline $\operatorname{del}($ leu $\operatorname{chl} J)$ & 8 & 12 \\
\hline $\operatorname{del}(\arg \operatorname{chl~K})$ & 2 & 5 \\
\hline $\operatorname{del}(\operatorname{trp} \operatorname{chl} L)$ & 2 & 4 \\
\hline $\operatorname{del}(g l u c h l A$ chl B nir) & 2 & 3 \\
\hline del (his chl M) & I & I \\
\hline
\end{tabular}

Table 3. Genetic classification of the single site chl mutants from Bacillus licheniformis sio26

Recombinants were scored on $\mathrm{NBYNO}_{3}$ plates which were incubated anaerobically as described. In each experiment controls were run to score revertants and for competence or transducibility.

\begin{tabular}{|c|c|c|c|c|}
\hline \multirow[b]{2}{*}{ Group } & \multicolumn{3}{|c|}{ Method employed } & \multirow[b]{2}{*}{ Total no. } \\
\hline & $\begin{array}{c}\text { Reciprocal } \\
\text { transformation }\end{array}$ & $\begin{array}{l}\text { Donor capacity } \\
\text { in transformation }\end{array}$ & $\begin{array}{l}\text { Reciprocal } \\
\text { transduction }\end{array}$ & \\
\hline $\operatorname{chl} A$ & 5 & I & - & 6 \\
\hline $\operatorname{chl} B$ & 2 & - & - & 2 \\
\hline $\operatorname{chl} C$ & I & - & - & I \\
\hline $\operatorname{chl} D$ & I & 3 & - & 4 \\
\hline $\operatorname{chl} E$ & 9 & 9 & $\ldots$ & 18 \\
\hline $\operatorname{chl} F$ & 2 & - & $\ldots$ & 2 \\
\hline chl $G$ & - & - & 2 & 2 \\
\hline $\operatorname{chl} H$ & - & - & 1 & I \\
\hline Total no. & 20 & I3 & 3 & 36 \\
\hline
\end{tabular}

Table 4. Identification of the auxotrophic genes deleted in chl deletion mutants of Bacillus licheniformis $\$ 244$

SPI 5 lysates were prepared from donor cells and tested for transducing capacity. The acceptors were transduced with these lysates and with an SI026 lysate to check their transducibility. Recombinants were scored on minimal medium plates, if necessary fortified with growth factors.

Donor

s937 del $(\operatorname{trp} \operatorname{chl} L)$

s948 del (leu chl I)

s950 del $(\arg \operatorname{chl} K)$

s959 del (his chl $M)$

sioos del (urachlJ)
Acceptor

SI 339 trp-1
SI329 leu-2 his-3
SI 333 arg-3
SI329 leu-2 his-3
SI 68 ura-I

Selected marker

$\begin{array}{ll}\text { trp } & - \\ \text { leu } & + \\ \text { arg } & - \\ \text { his } & - \\ \text { ura } & -\end{array}$

acceptors in transduction and transformation crosses conducted as described in the previous section. The $g l u$ deletion comprises the genes $c h l A$ and $B$. All other deletion and single site mutations are different. Possibly therefore 13 genes may be involved in chlorate resistance: the genes $A$ to $H$ and the genes in the $u r a, l e u, \arg , \operatorname{trp}$ and his regions designated chl $I, J, K, L$ and $M$ respectively.

Identification of the auxotrophic markers in the deletions. In Bacillus licheniformis a number of auxotrophic markers have been mapped. To identify the auxotrophic genes in the deletion mutants, SPI5 donor lysates were prepared from the deletion mutants and auxotrophic mutants with markers at known map positions were transduced with these lysates (Table 4). We conclude that the leu mutation in the deletion is not the leu-2 gene. The $u r a, h i s, \arg$ and trp genes in the deletions are $u r a-I, h i s-3, \arg -3$ and $\operatorname{trp}-I$ respectively. 

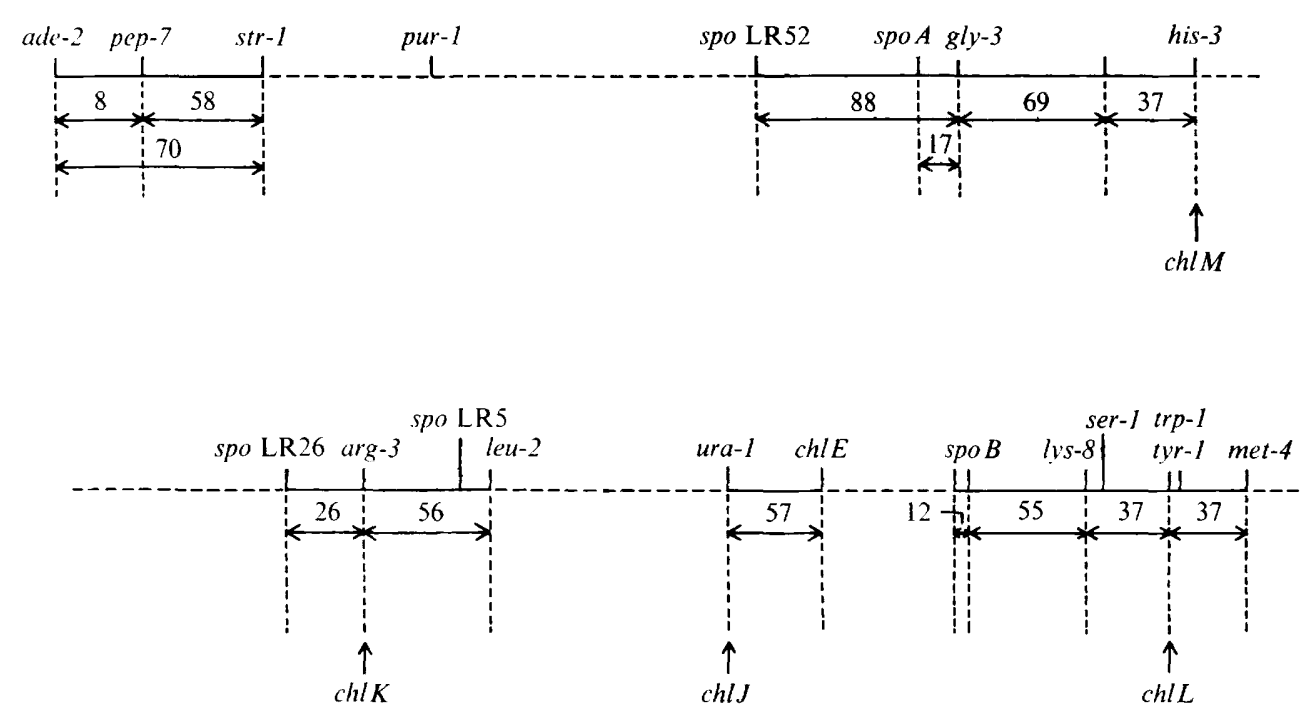

Fig. I. Chromosome map of Bacillus licheniformis after Tyeryar et al. (1968), Rogolsky (I970) and McCuen \& Thorne (I97I), showing the position of some chl-markers. Solid lines indicate linkage in SPI5-mediated transduction crosses. Dashed lines indicate absence of linkage; their length is arbitrary. The approximate positions of chl-markers, found by deletion mapping, are indicated by arrows. The numbers represent distances in linkage units between two markers (calculated at $100 \%$ co-transduction).

$C h l J, K, L$ and $M$ are therefore in the $u r a-I$, his-3, arg-3 and trp-I regions. In Fig. I their approximate map position has been indicated by arrows. Localization of the $\operatorname{chl} A$ and $B$ genes was not possible because a single site $g l u$ mutant was not available.

Mapping chl markers by SPI5-mediated transduction. SPI5 donor lysates were prepared from chl strains and all auxotrophic strains listed in Table I were used as acceptors in transduction crosses. Prototrophic recombinants were scored and tested for chl properties. Linkage of $c h l$ and spo markers was studied using the spo strains as donors and the $c h l$ strains as acceptors. Chlorate-sensitive recombinants were scored on $\mathrm{NBYNO}_{3}$ plates and then tested for spo properties.

$C h l E$ is $43 \%$ linked to ura-1 but unlinked to either $s p o-B$ or leu-2 the markers on either side of ura with which ura is not linked. Consequently the order $u r a-I$-chl $E$ relative to the replication origin cannot be determined (Fig. I).

The other chl markers were not located, most likely because they are outside the mapped regions of the Bacillus licheniformis chromosome.

Nitrate and nitrite reduction in chl mutants. None of the $c h l$ mutants was able to grow anaerobically with nitrate as a sole electron acceptor. No nitrite, nor reduced benzyviologennitrate oxidoreductase was produced after a shift from aerobic to anaerobic conditions. Trace amounts of nitrite were formed after prolonged incubation with nitrate.

No mutant was affected in nitrate and nitrite assimilation with the possible exception of the $g l u$ deletion mutants. These mutants require glutamic acid in the medium which acts as a repressor of the assimilative nitrate reductase (Cove, I966, Downey \& Nuner, 1967) so that nitrate assimilation cannot be tested.

Only the $g l u$ deletion mutants and one $\operatorname{chl} A$ mutant SI 279 are unable to reduce nitrite (nir). This is not a pleiotropic effect of the $c h l A$ mutation as the other $c h l A$ mutants are $n i r^{+}$, but it is caused by a separate mutation in the same genetic region. SI 279 should be 


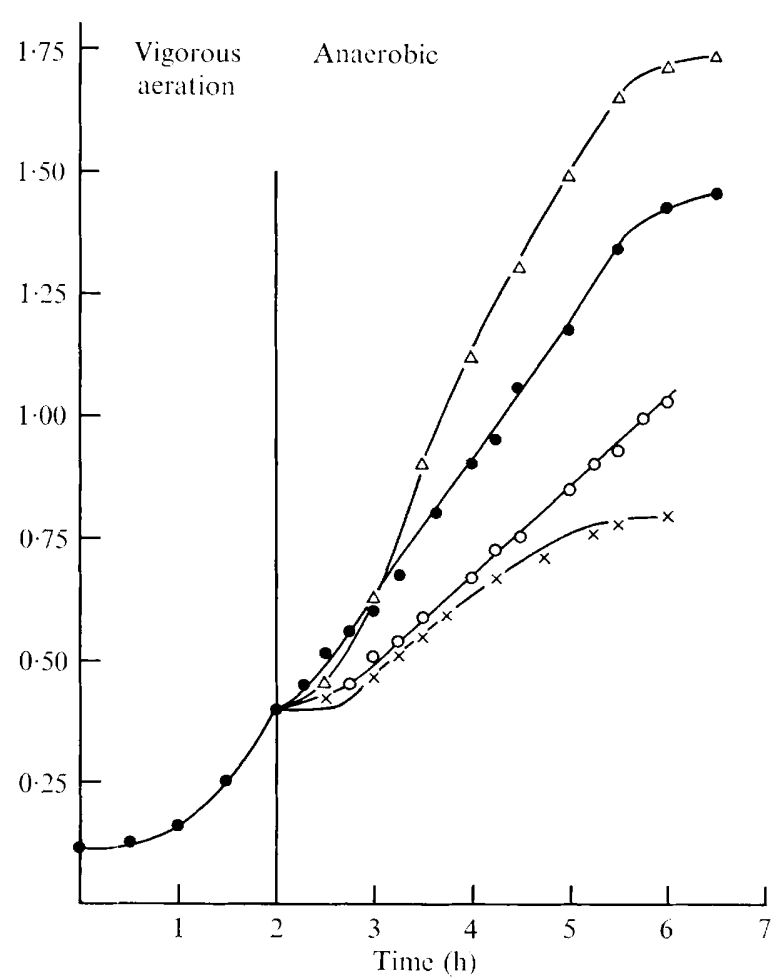

Fig. 2. Growth rates of Bacillus licheniformis wild-type and mutants after a shift from aerobic to anaerobic conditions. $\triangle$, s244 wild-type in $\mathrm{NBYGNO}_{3} ; \mathrm{O}, \mathbf{s} 244$ wild-type in NBYG; 0 , s950 del $(\arg c h l K)$ in NBYG and $\mathrm{NBYGNO}_{3} ; \times$, s950 del (his chl $M$ ) in NBYG and NBYGNO . $^{\text {N }}$

Table 5. Acid formation of Bacillus licheniformis $\mathbf{3 2 4 4}$ wild-type and some chl mutants after anaerobic cultivation in NBYG

Averages of two experiments are given.

$\begin{array}{lccccc}\text { Strain } \ldots & \text { S244 } & \text { S970 } & \text { S959 } & \text { S950 } & \text { SI005 } \\ \text { Acid formation } & \mathrm{II} \cdot \mathrm{I} & \mathrm{I} 2 \cdot 9 & \mathrm{I} 5 \cdot \mathrm{I} & 8 \cdot 9 & 2 \mathrm{I} \cdot 7 \\ (\mu \mathrm{mol} / \mathrm{mg} \text { protein } / \mathrm{h}) & & & & & \end{array}$

considered a deletion mutant, because it bears two mutations, does not revert and cannot act as an acceptor in crosses.

Glaser \& de Moss (I97I) have observed restoration of nitrate reductase activity in chl D mutants of Escherichia coli by addition of $1 \mathrm{O}^{-4} \mathrm{M}$-molybdate. We did not observe this effect in any of the Bacillus licheniformis chl mutants.

Growth characteristics of chl mutants. In strain s244 wild-type anaerobic growth with glucose is stimulated by the addition of nitrate (Schulp \& Stouthamer, 1970).

Anaerobic growth of mutants is not stimulated by addition of nitrate and all mutants except ura deletion mutants show retarded growth under anaerobic conditions; some do not reach a higher extinction than $E 660=0.8$ (Fig. 2). Their glycolytic activities show some variation but from these figures it is clear that retarded fermentation cannot account for the retarded growth (Table 5).

When the mutants are cultivated with weak aeration, their growth rate decreases as soon 
Table 6. Protein and nitrate reductase content of cell fractions

The membrane fraction contained 2300 units of nitrate reductase after osmotic shock and centrifugation. Three hundred and eighty units are lost during washing with $\mathrm{I} \mathrm{M}-\mathrm{NaCl}+0.02 \mathrm{M}-\mathrm{MgSO}_{4}$.

\begin{tabular}{|c|c|c|c|}
\hline & $\begin{array}{c}\text { Protein }[\mathrm{mg} / \mathrm{l} \text { of } \\
\text { culture }(E 660=\mathrm{I} \cdot 0)]\end{array}$ & $\begin{array}{l}\text { Nitrate reductase } \\
\text { [Units/l of culture } \\
(E 660=\mathrm{I} \cdot 0)]\end{array}$ & $\begin{array}{l}\text { Nitrate reductase } \\
\text { (sp. activity, } \\
\text { units/mg protein) }\end{array}$ \\
\hline Crude sonicate & 185 & 2400 & I3 \\
\hline Membranes & 37 & 1920 & 52 \\
\hline Mesosomes & $2 \cdot 4$ & $17 \cdot 6$ & $7 \cdot 3$ \\
\hline Supernatant of mesosomes & N.D. & 0 & 0 \\
\hline
\end{tabular}

as the oxygen supply becomes limiting. Even under these conditions no nitrate reductase or nitrite is formed.

These results indicate that pleiotropic effects of chl mutations in Bacillus licheniformis are very different from those in Enterobacteriaceae, where growth rates are not influenced by chl mutations (Piéchaud et al. 1967; Stouthamer, 1967).

Aerobically, growth rate, oxygen uptake with different substrates, and cytochrome spectra of mutants did not differ from those of the wild-type.

Antibiotic sensitivity of chl mutants. The two parent strains and all types of chl mutants were tested for their sensitivities to a selection of antibiotics and chemotherapeutics. All the single-site mutants, chl $A$ and $F$ excepted, had an increased sensitivity to penicillin and its structural analoga ampicillin, methicillin, carbenicillin and cephaloridin. All these antibiotics interfere with cell wall synthesis.

Localization of nitrate reductase in the cell. Strain $\$ 244$ wild-type was cultivated anaerobically in $\mathrm{NBYGNO}_{3}$ to $E 660=\mathrm{I} \cdot 0$. From I 1 of culture membrane and mesosome fractions were prepared. From $100 \mathrm{ml}$ of the culture a crude sonic extract was prepared. Protein content and nitrate reductase activity of these preparations were determined (Table 6). Nearly all nitrate reductase is located in the membranes. Specific and total nitrate reductase activities in the mesosomes are insignificant. Therefore, only the protein composition of the membranes has been studied.

The $c$-type cytochrome, $\alpha=553$, was also located in the membranes.

Contamination of the membrane and mesosome fractions. Membranes from Bacillus licheniformis isolated according to Reaveley \& Rogers (1969) contained little or no cytoplasmic proteins. The main contamination was RNA, especially when isolation was performed in the presence of $0.02 \mathrm{M}-\mathrm{MgSO}_{4}$ and it could not be completely removed. Similar observations have been found by Yudkin \& Davis (I965), Coleman (I969) and van Dijk-Salkinoja et al. (1970).

Electron micrographs of thin sections of Bacillus licheniformis $\$ 244$ membranes revealed the presence of vast amounts of ribosomes (Fig. 3), so ribosomal protein bands are to be expected in acrylamide gels of the membrane fraction. Flagella were present in the mesosome fraction, not in the membrane fraction as observed in negatively stained specimens.

Distinction between ribosomal and membrane proteins. Attempts were made to achieve a separation of ribosomal and membrane proteins. For this purpose, the membranes were solubilized by the method of van Dijk-Salkinoka et al. (1970). In this way a mixture of insoluble components, ribosomes and solubilized membrane protein was obtained. The purified membrane proteins were isolated by differential centrifugation and subjected to 

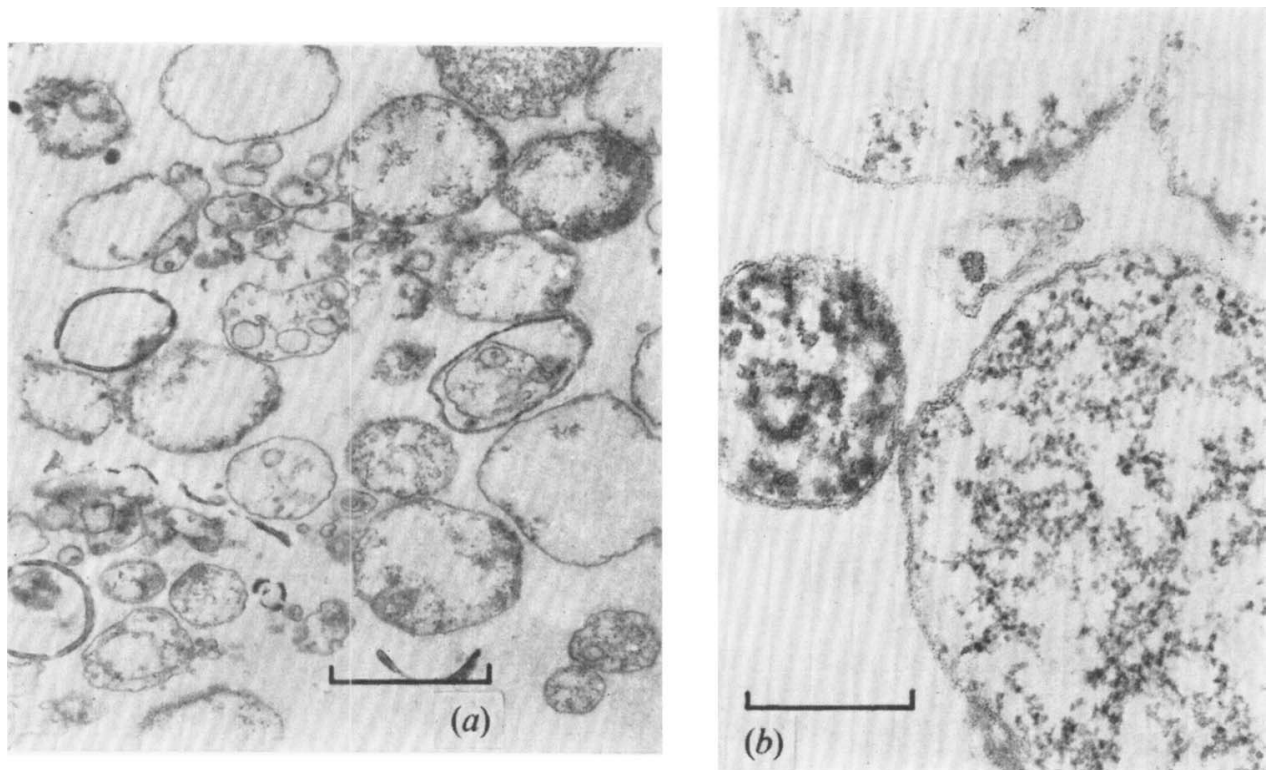

Fig. 3. Thin sections of the membranes of Bacillus licheniformis $\mathbf{s} 244$ at two different magnifications. Included ribosomes are clearly visible. There is a slight contamination with cell wall material. Scale bars equal $5 \mu \mathrm{m}$.
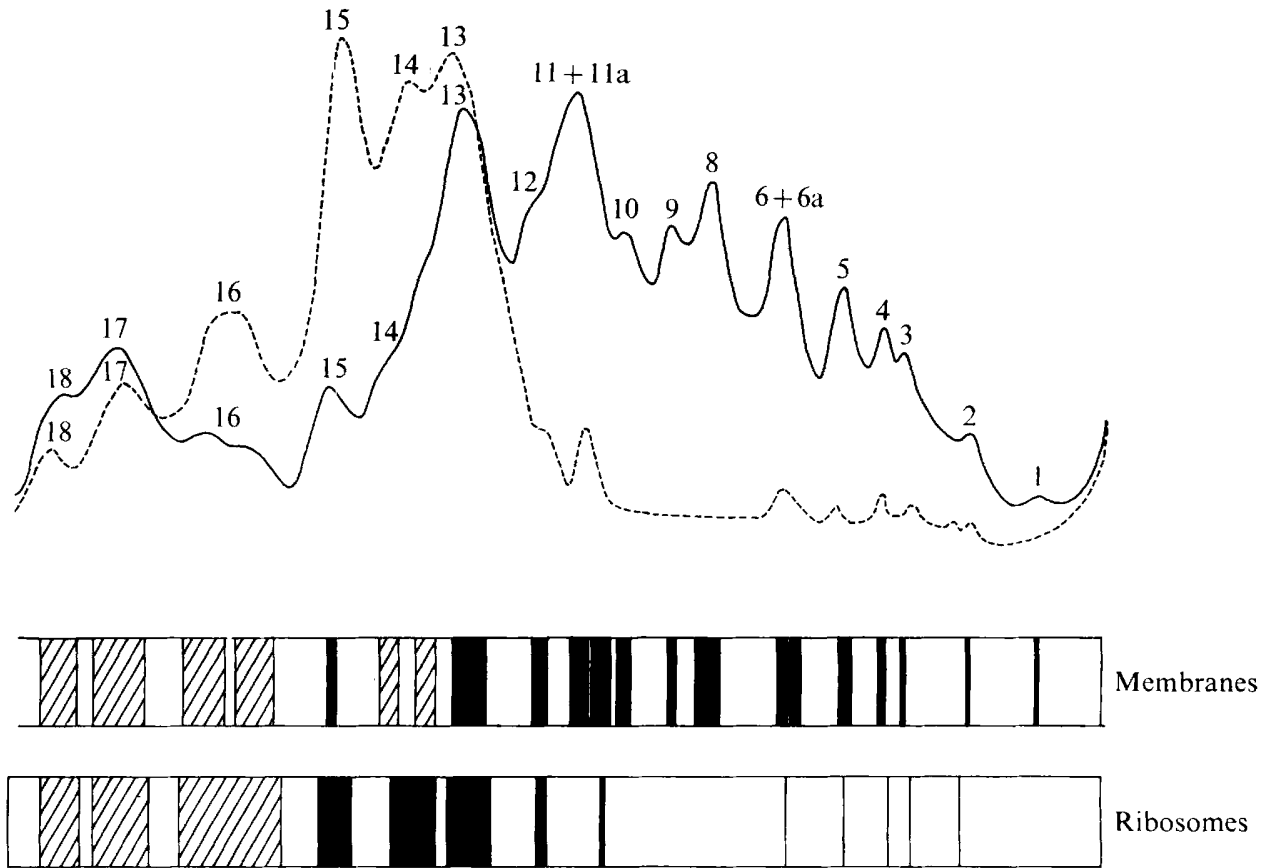

Fig. 4. Absorbance scans of polyacrylamide gels of Bacillus licheniformis $\mathbf{S 2 4 4}$ membranes (- - ) and ribosomes (-- - ). Below the scan is a representation of the gel. Some bands which appear as one peak on the scans are actually two very close bands $(6,6 \mathrm{a}, \mathrm{II}, \mathrm{I}$ I a). Hatching indicates diffuse bands. 


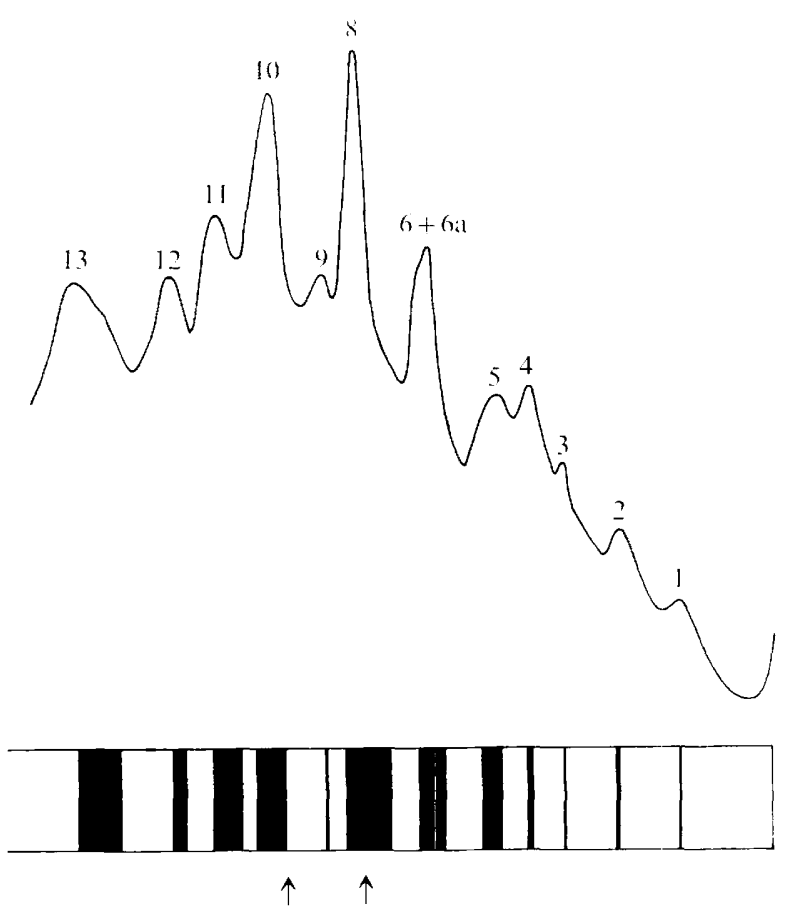

Fig. 5. Absorbance scan of a polyacrylamide gel of Bacillus licheniformis \$244 membrane proteins, after anaerobic cultivation in $\mathrm{NBYGNO}_{3}$. Below the scan is a representation of the gel. Arrows indicate differences with membrane proteins of cells cultivated aerobically in $\mathrm{NBYGNO}_{3}$. Only bands I up to 13 are shown.

\section{Table 7. Molecular weights of the membrane proteins of Bacillus licheniformis}

Molecular weight of proteins were determined electrophoretically by the method of Weber \& Osborne (1969).

$\begin{array}{lccc}\text { No. } & \begin{array}{c}\text { Molecular weight } \\ \text { (daltons) }\end{array} & \text { No. } & \begin{array}{c}\text { Molecular weight } \\ \text { (daltons) }\end{array} \\ \text { I } & \text { I } 33000 & 7 * & 59000 \\ 2 & \text { I I0000 } & 8 & 55000 \\ 3 & 96000 & 9 & 48000 \\ 4 & 86000 & \text { IO } & 43000 \\ 5 & 78000 & 1 \text { I }+ \text { I I } a & 37000 \\ 5 a^{*} & 70000 & \text { I } 2 & 32000 \\ 6+6 a & 66000 & & \end{array}$

polyacrylamide gel electrophoresis as described. Only four protein bands were detected in the purified membrane protein fraction. All cytochromes remained in the insoluble fraction. Complete separation of ribosomes and membrane proteins was impossible, therefore the ribosomal proteins have been identified by comparing polyacrylamide gels of purified ribosomes and membranes (Fig. 4). The protein bands found in wild-type and mutant membranes have been numbered from I to I 8 but one protein band may consist of a mixture of several proteins.

Protein bands I to 12 were hardly or not at all found in the ribosomes, but the ribosomes were enriched for protein bands 13 to 18 compared with the membranes. The maximum 
Table 8. Comparison of the membrane protein patterns of chl mutants with the wild-type after anaerobic cultivation in $\mathrm{NBYGNO}_{3}$

sioo5 del (ura chlJ) s937 del (trp chl L) s948 del (leu chl I) s950 del (arg chl $K)$ s959 del (his chl $M$ ) s970 del (glu chl A chl B nir) SI I $82 \operatorname{chl} A$ SI I $86 \operatorname{chl} B$
Protein band in which change is observed

$\begin{array}{ccccccc}\text { I } & 2 & 3 & 5 & 6 & 7 & 8 \\ + & ++ & 0 & 0 & 0 & p & 0 \\ 0 & 0 & 0 & d & 0 & p & 0 \\ 0 & 0 & 0 & d & 0 & p & - \\ \mathrm{a} & ++ & 0 & \mathrm{~d} & - & \mathrm{p} & 0 \\ 0 & 0 & 0 & \mathrm{~d} & 0 & \mathrm{p} & \mathrm{a} \\ 0 & 0 & - & \mathrm{d} & 0 & 0 \\ 0 & + & 0 & 0 & 0 & 0 & 0 \\ 0 & ++ & - & 0 & 0 & 0 & 0\end{array}$

a, Absent in the mutant but present in the wild-type.

$\mathrm{p}$, Present in the mutant but absent in the wild-type.

d, Doubling of band.

+ , Increase.

++ , Large increase.

- , Decrease.

$o$, No change from wild-type.

molecular weight of ribosomal proteins, apart from a minor component of mol.wt 65000 , varies according to different data from 28300 to 33000 (Dzionara, Kaltschmidt \& Wittman, I970; Garrett, Rak, Daya \& Stöffler, I97I). Protein bands I to I 2 are therefore considered as true membrane proteins (Table 7 ). Bands 13 to 18 consist mainly of ribosomal protein but some membrane proteins may to be present which are completely masked by ribosomal proteins.

It was impossible to detect nitrate reductase on these gels, as solubilization of the membranes with I \% SDS causes a complete inactivation of nitrate reductase.

Influence of cultural conditions upon the membrane protein composition of wild-type. $\mathbf{5} 244$ was cultivated aerobically and anaerobically in $\mathrm{NBYGNO}_{3}$. Membranes were isolated and their protein composition was analysed. There are only a few quantitative differences between the membrane protein pattern of aerobic and anaerobic cells (Fig. 4, 5). The most pronounced effects are increases of bands 8 and 10.

Alterations in membrane protein composition of chl mutants after anaerobic cultivation. A selection of the mutants were cultivated anaerobically and their membrane protein composition was analysed. As the mutants had been derived from two different parent strains, these parent strains $\$ 244$ and sI026 were compared for their membrane protein patterns and no differences were found.

Each mutant has its own characteristic and reproducible pattern of membrane protein bands. Most of the differences, however, occurred in more than one type of mutant. Changes were observed in the amounts of protein in bands I, 2, 3, 5, 6, 7 and 8 (see Table 8).

A very pronounced effect is the large increase in the amount of protein band 2 . This is shown in Fig. 6 for s950 del $(\arg \operatorname{chl} K)$. There is a doubling of band 5, a decrease in the amount of protein in band 6 and the appearance of band 7 .

The absence of protein band 8 in 5959 del (his chl M) is shown in Fig. 7 as well as the presence of band 7 and doubling of band 5 .

Alterations in membrane protein composition of chl mutants after aerobic cultivation. Effects of chl mutations were produced mainly under anaerobic conditions. Aerobically, 


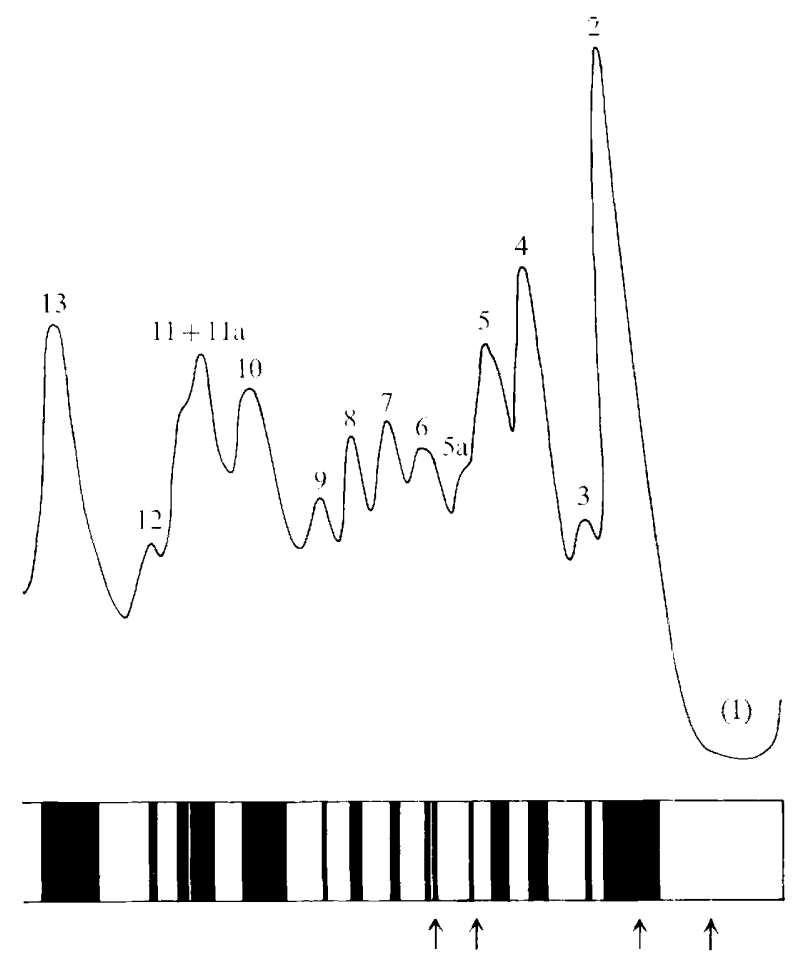

Fig. 6. Absorbance scan of a polyacrylamide gel of Bacillus licheniformis s950 del (arg chl K) membrane proteins, after anaerobic cultivation in $\mathrm{NBYGNO}_{3}$. The arrows indicate differences with s244 wild-type cultivated under the same conditions. Only bands I up to I3 are shown.

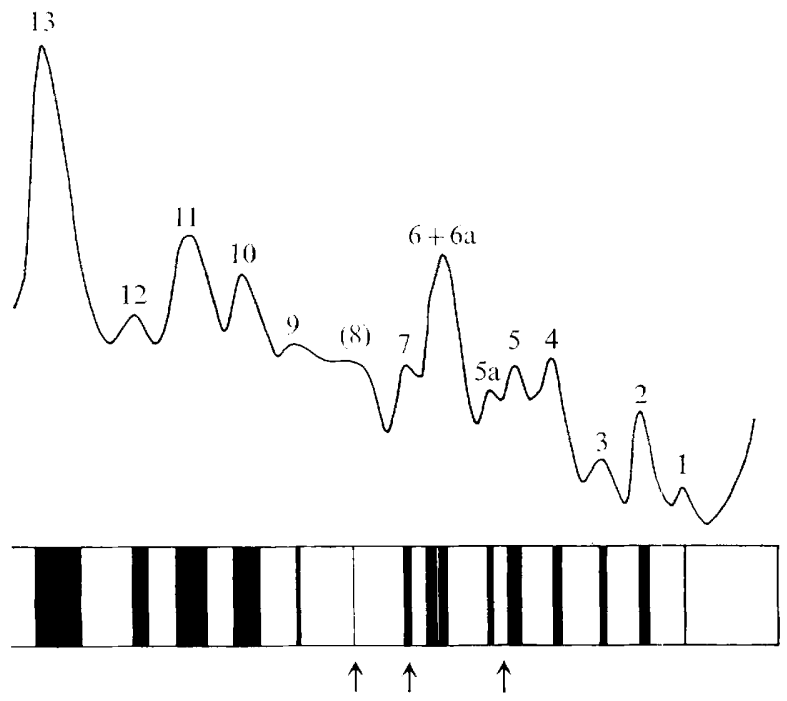

Fig. 7. Absorbance scan of a polyacrylamide gel of Bacillus licheniformis $\mathrm{s} 959$ del (his chl $M$ ), membrane proteins after anaerobic cultivation in $\mathrm{NBYGNO}_{3}$. The arrows indicate differences with S244 wild-type cultivated under the same conditions. Only bands I up to 13 are shown. 


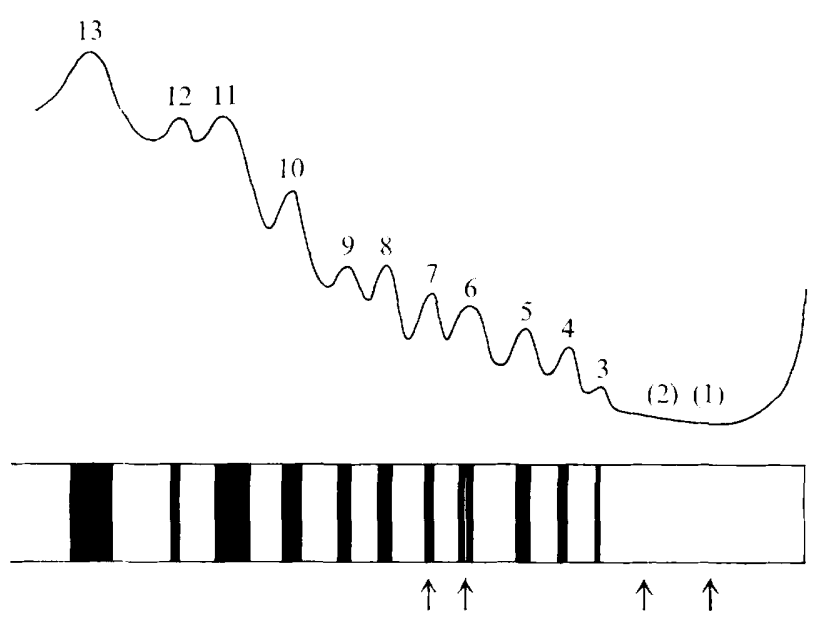

Fig. 8. Absorbance scan of a polyacrylamide gel of Bacillus licheniformis s950 del (arg chl K) membrane proteins, after aerobic cultivation in $\mathrm{NBYGNO}_{3}$. The arrows indicate differences with s244 wild-type cultivated under the same conditions. Only bands I up to 13 are shown.

Table 9. Comparison of the membrane protein patterns of chl mutants with the wild-type, after aerobic cultivation in $\mathrm{NBYGNO}_{3}$

\begin{tabular}{|c|c|c|c|c|c|}
\hline & & ba & $\mathrm{h} \mathrm{cl}$ & ser & \\
\hline & I & 2 & 6 & 7 & 8 \\
\hline s948 chl J & 0 & 0 & 0 & $\mathrm{p}$ & 0 \\
\hline s950 chl K & a & a & - & $\mathrm{p}$ & 0 \\
\hline s937 $\mathrm{chl} L$ & a & a & 0 & $\mathrm{p}$ & 0 \\
\hline s959 chl $M$ & a & $\mathrm{a}$ & - & $\mathrm{p}$ & a \\
\hline s970 chl $A$ chl $B$ & a & a & 0 & $\mathrm{p}$ & 0 \\
\hline
\end{tabular}

no effects of $c h l$ mutations were observed. It seemed worth while to investigate the membrane protein composition of the $c h l$ mutants after aerobic cultivation to distinguish constitutive and inducible differences.

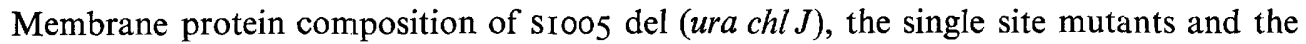
wild-type are identical. All other deletion mutants have protein band 7 which is lacking in the wild-type. Other differences, the absence of protein bands $I$ and 2 and decrease of protein band 6, occur in some other mutants.

Protein band 8 is lacking in s959 del (his chl $M$ ) both aerobically and anaerobically an important characteristic of this mutant. The differences in membrane protein composition are summarized in Table 9. To show the large difference between the membrane protein pattern after aerobic and anaerobic cultivation the densitogram of $\$ 950$ membrane protein from aerobic cells is shown in Fig. 8.

\section{DISCUSSION}

Deletion mapping has proved extremely useful in mapping chl loci of several Enterobacteriaceae (Adhya et al. I968; Stouthamer, I969; Stouthamer \& Pietersma, 1970). In these organisms deletions comprising up to eight genes have been found (Stouthamer, 1969).

The auxotrophic chl mutants obtained from Bacillus licheniformis $\$ 244$ are considered 
as deletion mutants for the following reasons: (i) they cannot revert nor be transduced or transformed to either prototrophy or chlorate sensitivity; (ii) mutants of the same type have been isolated repeatedly in independent experiments; (iii) mutagenic treatment yields only single auxotrophs at a very low frequency. In contrast, without mutagenic treatment, plating on NBYGChl is a selective method only, yet chl-auxotrophic double mutants were obtained at high frequency; (iv) the $g l u$ deletion comprises four genes: $g l u, \operatorname{chl} A, \operatorname{chlB}$, nir ; (v) the $c h l$ genes deleted are all different as they cause different membrane protein patterns.

Most deletions comprise only one $c h l$ and one auxotrophic gene; this may be a consequence of the fact that the chromosome of Bacillus licheniformis is less well marked than that of Escherichia coli.

The number of single site $c h l$ mutations, eight, seems high and one might wonder whether these mutations are in eight different genes. Both $c h l A$ and $c h l B$ are situated near $g l u$, yet they are phenotypically different. $C h l E$ is the only gene mapping near ura. The five remaining mutations have not been mapped. $C h l F$ is phenotypically different from the rest (penicillin sensitivity). For the mutations $c h l C, D, G$ and $H$ the possibility cannot be ruled out that they are within the same gene or cistron. However, van Hartingsveldt, Marinus \& Stouthamer (1971) employed a similar technique for classification of Pseudomonas aeruginosa chl mutants. These mutations have been mapped by conjugation (van Hartingsveldt \& Stouthamer, 1973) and they are at different sites on the chromosome and therefore in different genes. Further mapping may reveal similar data for the Bacillus licheniformis chl mutations as well.

Bacillus licheniformis chl mutants differ markedly from Enterobacteriaceae, chl mutants in their pleiotropic effects. In Enterobacteriaceae pleiotropic effects are limited to effects upon reductases and formic dehydrogenase complex; all of them are properties connected with anaerobic electron transport. In B. licheniformis chl mutations cause (i) absence of nitrate reductase under conditions of oxygen shortage, (ii) decrease in growth rate under anaerobic conditions, (iii) increased sensitivity to penicillin and related antibiotics, (iv) very complex changes in membrane protein patterns mainly under anaerobic but also under aerobic conditions. In some of the single-site mutants all these changes are found. It may be concluded that these changes are due to the pleiotropic effects of one mutation since revertants to chlorate sensitivity behave like wild-type in all these properties.

We believe that the increased penicillin sensitivity in some mutants is due to a pleiotropic effect of $\mathrm{chl}$ mutations on cell wall synthesis, which is a membrane-bound process (Araki et al. 1966; Izaki, Matsuhashi \& Strominger, 1966, I968). Evidence exists both for Escherichia coli and Bacillus subtilis that the targets for penicillin are situated on the membrane (Cooper, 1956; Lawrence \& Strominger, I970; Hartman, Höltje \& Schwarz, 1972).

The changes in membrane protein patterns produced in Bacillus licheniformis by the $\mathrm{chl}$ mutations are very complex and important compared with changes produced in Escherichia coli by such mutations as chl, tol, dna (Inouye \& Pardee, 1970; Samson \& Holland, I970; Shapiro, Siccardi, Hirota \& Jacob, I970; McGregor \& Schnaitman, 197I). In all these cases the main differences are observed in one or two protein bands only. In contrast, $B$. licheniformis chl mutants cultivated anaerobically have important alterations in two to five protein bands.

The explanation for all these changes may be a wholesale disorganization of protoplasmic membrane biosynthesis. Consequently, it is hard to say whether the pleiotropic effects are consequences of the chlorate resistance or the chlorate resistance a consequence of, for instance, the antibiotic sensitivity. In this respect symbol chl may be considered a phenotypic, not a genotypic designation for some of the mutants. 
The present investigations have been sponsored by the Netherlands Foundation for Chemical Research (S.O.N.) and the Netherlands Organization for the Advancement of pure Research (Z.W.O.). The authors are much indebted to Dr D. J. Sherratt, Edinburgh, Dr Marvin Rogolsky, Utah, and Dr C. B. Thorne, Amherst (Massachusetts) for their gifts of phage and strains, and for their good advice; to Drs Joh. Brouwer and T. J. Stoof, Biochemisch Laboratorium der Vrije Universiteit, for their gifts of ribosomes and for their advice; and to Mrs E. A. Oltmann-Spanjaerdt Speckmann, Mrs M. J. P. Giele-Pallandt, Mr J. D. H. van der Lely, Mr E. H. Veltkamp, Mr D. J. W. Meijers and Mr D. Barendregt for their excellent technical assistance. The electronmicrographs have been made by $\mathrm{Mr}$ E. H. Veltkamp at the Laboratorium voor Electronenmicroscopie of the Gemeentelijke Universiteit van Amsterdam, director Mrs Dr W. van Iterson.

\section{REFERENCES}

Adhya, S., Cleary, P. \& CAMpbell, A. (1968). A deletion analysis of prophage $\lambda$ and adjacent genetic regions. Proceedings of the National Academy of Science of the United States of America 6r, 956-962.

Araki, Y., Shirai, R., Shimada, N., Ishimoto, N. \& Ito, E. (1966). Enzymatic synthesis of cell wall mucopeptide in a particulate preparation of Escherichia coli. Biochemical and Biophysical Research Communications 23, 466-472.

Coleman, G. (1969). Effect of potassium ions on the attachment of polyribosomes to the membranes in lysates of exponential phase cells of Bacillus amyloliquefaciens. Biochemical Journal 112, 533-540.

COOPER, P. D. (1956). Site of action of radiopenicillin. Bacteriological Reviews 20, 28-48.

Cove, D. J. (1966). The induction and repression of nitrate reductase in the fungus Aspergillus nidulans. Biochimica et biophysica acta $\mathrm{II}_{3}, 5 \mathrm{I}-56$.

van Dijk-S alkinoja, M. S., Stoof, T. J. \& Planta, R. J. (1970). The distribution of polysomes, ribosomes and ribosomal subunits in exponential phase cells of Bacillus licheniformis. European Journal of Biochemistry 12, 474-482.

DOWNEY, R. J. \& NUNER, J. H. (1967). Induction of nitrate reductase under conditions of nitrogen depletion. Life Sciences 6, 855-861.

Dzionara, M., Kaltschmidt, E. \& WittmanN, H. G. (1970). Ribosomal proteins. XIII. Molecular weights of isolated ribosomal proteins of Escherichia coli. Proceedings of the National Academy of Sciences of the United States of America 67, 1909-19I3.

Garret, R. A., RAK, K. H., DAYA, L. \& StÖFfler, G. (1971). Ribosomal proteins. XXIX. Specific protein binding sites on I6 S rRNA of Escherichia coli. Molecular and General Genetics II4, I I2-I 24.

GLASER, J. H. \& DE Moss, J. A. (197I). Phenotypic restoration by molybdate of nitrate reductase activity in chl D mutants of Escherichia coli. Journal of Bacteriology 108, 854-860.

De Groot, G. N. \& Stouthamer, A. H. (1969). Regulation of reductase formation in Proteus mirabilis. I. Formation of reductases and enzymes of the formic hydrogenase complex in the wild type and in chlorate resistant mutants. Archiv für Microbiologie 66, 220-233.

GuEST, J. R. (1969). Biochemical and genetic studies with nitrate reductase C-gene mutants of Escherichia coli. Molecular and General Genetics 105, 285-297.

Gwinn, D. D. \& ThORNE, C. B. (1964). Transformation of Bacillus licheniformis. Journal of Bacteriology 87, $519-526$.

de HaAn, P. G., Stouthamer, A. H., Felix, H. S. \& Mol, A. K. (1963). Transfer of F ${ }^{1}$ from Escherichia coli $\mathrm{K} 12$ to Escherichia coli $\mathrm{B}$ and to strains of Paracolobacter and Klebsiella. Antonie van Leeuwenhoek 29, 407-420.

van Hartingsveldt, J., Marinus, M. G. \& Stouthamer, A. H. (1971). Mutants of Pseudomonas aeruginosa blocked in nitrate or nitrite dissimilation. Genetics 67, 469-482.

van Hartingsveldt, J. \& Stouthamer, A. H. (I973). Mapping and characterization of mutants of Pseudomonas aeruginosa affected in nitrate respiration, in aerobic and anaerobic growth. Journal of General Microbiology (in the press).

Hartman, K., Höltje, J. V. \& Schwarz, U. (1972). Targets of penicillin in Escherichia coli. Nature, London 235, 426-429.

INOUYE, M. \& PARDEE, A. B. (1970). Changes of membrane proteins and their relation to deoxyribonucleic acid synthesis and cell division in Escherichia coli. Journal of Biological Chemistry 245, 5813-5819. 
Izaki, K., Matsuhashi, M. \& Strominger, J. L. (1966). Glycopeptidetranspeptidase and D-alanine carboxypeptidase: penicillin sensitive enzymatic reactions. Proceedings of the National Academy of Sciences of the United States of America 55, 656-663.

Izaki, K., Matsuhashi, M. \& Strominger, J. L. (1968). Biosynthesis of peptidoglycan. XIII. Peptidoglycan transpeptidase and D-alanine carboxypeptidase: penicillin-sensitive reactions in strains of Escherichia coli. Journal of Biological Chemistry 243, 3180-3192.

LAwrence, P. J. \& Strominger, L. J. (1970). The binding of radioactive penicillin to the particulate enzyme preparation of Bacillus subtilis and its reversal with hydroxylamine or thiols. Journal of Biological Chemistry 245, 3653-3659.

Lowe, R. H. \& Evans, H. J. (I964). Preparation and some properties of a soluble nitrate reductase of Rhizobium japonicum. Biochemica et biophysica acta 85, 377-389.

Lowry, O. H., Rosebrough, N. J., Farr, A. L. \& Randall, R. J. (1951). Protein measurement with the Folin phenol reagent. Journal of Biological Chemistry 193, 265-275.

MCCuen, R. W. \& Thorne, C. B. (I97I). Genetic mapping of genes concerned with glutamyl polypeptide production by Bacillus licheniformis and a study of their relationship to transformation. Journal of Bacteriology 107, 636-645.

McGregor, C. H. \& Schnaitman, C. A. (197I). Alterations in the cytoplasmic membrane proteins of various chlorate-resistant mutants of Escherichia coli. Journal of Bacteriology 108, 564-570.

ONODERA, K., Rolfe, B. \& BernsteIn, A. (1970). Demonstration of missing proteins in deletion mutants of E. coli K I2. Biophysical and Biochemical Research Communications 39, 969-975.

PARSON, D. F., (I963). Mitochondrial structure: two types of subunits on negatively stained mitochondrial membranes. Science, New York 140, 985-987.

Piéchaud, M., Puig, J., Pichinoty, F., Azoulay, E. \& Le Minor, L. (1967). Mutations affectant la nitrate réductase A et d'autres enzymes bactériennes d'oxydoréduction. Étude préliminaire. Annales de l'Institut Pasteur I12, 24-37.

Puig, J. \& Azoulay, E. (1967). Étude biochimique et génétique des mutants résistants au $\mathrm{ClO}_{3}{ }^{-}$(gènes $C h l A, C h l B, C h l C$ ). Comptes rendus de l'Académie des sciences 264, 1916-1918.

Puig, J., Azoulay, E., Gendre, J. \& Richard, E. (1969). Étude génétique des mutants de la région $c h l A$ chez l'Escherichia coli. Comptes rendus de l'Académie des sciences 268, 183-184.

Reaveley, D. A. \& Rogers, H. J. (1969). Some enzymic activities and chemical properties of the mesosomes and cytoplasmic membranes of Bacillus licheniformis 6346. Biochemical Journal 113, 67-97.

Rogolsky, M. (1969). Chromosomal regions which control sporulation in Bacillus subtilus. Canadian Journal of Microbiology 15, 787-792.

RogolsKy, M. (1970). The mapping of genes for spore formation on the chromosome of Bacillus licheniformis. Canadian Journal of Microbiology 16, 595-600.

Ruiz-Herrera, J., Showe, M. K. \& De Moss, J. A. (1969). Nitrate reductase complex of Escherichia coli K I2: isolation and characterization of mutants unable to reduce nitrate. Journal of Bacteriology 97 , $1291-1297$.

Ryter, A. \& Kellenberger, E. (1958a). Étude au microscope électronique de plasmas contenant l'acide déoxyribonucleique. I. Les nucléides des bactéries en croissance active. Zeitschrift für Naturforschung 136, 597-605.

RYTER, A. \& Kellenberger, E. (1958b). L'inclusion au polyester pour l'ultramicrotomie. Journal of Ultrastructural Research 2, 200-214.

Samson, A. C. R. \& Holland, J. B. (I970). Envelope protein changes in mutants of Escherichia coli refractory to colicin E. FEBS Letters II, 33-36.

Sanderson, K. E. (1970). Current linkage map of Salmonella typhimurium. Bacteriological Reviews 34, $176-193$.

Schnaltman, C. A. (1969). Alteration of membrane proteins in a chlorate resistant mutant of Escherichia coli. Biophysical and Biochemical Research Communications 37, I-5.

SChulp, J. A. \& Stouthamer, A. H. (1970). The influence of oxygen, glucose and nitrate upon the formation of nitrate reductase and the respiratory system in Bacillus licheniformis. Journal of General Microbiology 64, $195-203$.

Shapiro, B. M., Siccardi, A. G., Hirota, Y. \& JacoB, F. (1970). On the process of cellular division in Escherichia coli. II. Membrane protein alterations associated with mutations affecting the initiation of DNA synthesis. Journal of Molecular Biology 52, 75-89.

STEMPAK, J. G. \& WARD, R. T. (1964). An improved staining method for electron microscopy. Journal of Cell Biology 22, 697-70I. 
Stouthamer, A. H. (1967). Nitrate reduction in Aerobacter aerogenes. I. Isolation and properties of mutant strains blocked in nitrate assimilation, and resistant against chlorate. Archiv für Mikrobiologie 56, 76-8o.

Stouthamer, A. H. (I969). A genetical and biochemical study of chlorate resistant mutants of Salmonella typhimurium. Antonie van Leeuwenhoek 35, 505-52 I.

Stouthamer, A. H. \& Bettenhaussen, C. W. (1970). Mapping of a gene causing resistance to chlorate in Salmonella typhimurium. Antonie van Leeuwenhoek 36, 555-565.

Stouthamer, A. H. \& Pietersma, K. (1970). Deletion mapping of resistance against chlorate in Klebsiella aerogenes. Molecular and General Genetics 106, I74-179.

TAYlor, M. J. \& GoldberG, J. D. (I97I). Growth and cultivation of the unusual generalized transducing Bacillus bacteriophage SP 15. Journal of Applied Microbiology 22, I I3-I I9.

TAylor, M. J. \& ThORne, C. B. (I963). Transduction of Bacillus licheniformis and Bacillus subtilis by each of two phages. Journal of Bacteriology 86, 452-46I.

ThORNE, C. B. (1962). Transduction in Bacillus subtilis. Journal of Bacteriology 83, ro6-I I I.

Thorne, C. B. \& STull, H. B. (1966). Factors affecting transformation of Bacillus licheniformis. Journal of Bacteriology 91, IOI2-IO20.

Tyeryar, F., Lawton, W. D. \& MCQuillan, A. M. (1968). Sequential replication of the chromosome of Bacillus licheniformis. Journal of Bacteriology 95, 2062-2069.

Venables, W. A. \& Guest, J. R. (I968). Transduction of nitrate reductase loci of Escherichia coli by phages $\mathrm{P}_{1}$ and $\mathrm{P}_{2}$. Molecular and General Genetics ro3, I27-I40.

Weber, K., \& Osborn, M. (1969). The reliability of molecular weight determinations by dodecyl sulphate polyacrylamide gel electrophoresis. Journal of Biological Chemistry 244, 4406-44I 2.

Yudkin, M. D. \& DAVIS, B. (I965). Nature of the RNA, associated with the protoplast membrane of Bacillus megaterium. Journal of Molecular Biology 12, 193-204. 